\title{
Strategi Penghidupan Berkelanjutan Masyarakat Sekitar Amal Usaha Muhammadiyah Pada Masa Covid 19 Di Taliwang Sumbawa Barat
}

\author{
${ }^{1}$ Ibrahim, ${ }^{2}$ Mintasrihardi, ${ }^{3}$ Mas'ad, ${ }^{4}$ Agus Herianto, 5 Junaidi AM , ${ }^{6}$ Kamaluddin \\ 1,3,4 Program Studi Pendidikan Geografi Universitas Muhammadiyah Mataram, Indonesia \\ 2, 5 Program Studi Ilmu Pemerintahan Universitas Muhammadiyah Mataram, Indonesia \\ ${ }^{6}$ Program Studi PKN Universitas Muhammadiyah Mataram, Indonesia \\ ibrahimali.geo@yahoo.com
}

\begin{abstract}
ARTICLE INFO
\section{Article History:}

Received : 25-09-2020

Revised : 05-11-2020

Accepted : 12-11-2020

Online : 30-11-2020

Keywords:

Strategi; Amal Usaha Muhammadiyah; Covid19

ABSTRACT

Abstract: Various government, institutional / private and community strategies in maintaining life during the Covid-19 period. The livelihood strategy of the people of Seloto Village as the center for the development of Muhammadiyah Business Charities (AUM) in West Sumbawa Regency. Have various livelihood strategies in the surrounding community. This study aims to examine the sustainable livelihood strategies of the community around Amal Usaha Muhammadiyah during the covid 19 period in Taliwang, West Sumbawa. The method used in this research is descriptive. The results of this study indicate that the first strategy, the intensification strategy, during the Covid-19 period was highest in Brang Pandan and Brang Bulu Hamlets, with an average of 18.15 and the lowest was in Brang Late Hamlet, reaching 37.47. The second strategy is the diversification strategy, during the Covid-19 period, the highest was in Lenang Late, with an average of 18.15 and the lowest was in Brang Bulu Hamlet at 13.30. And the third strategy, the migration strategy during the Covid-19 period, both from the three hamlets, were on average low at 2 . Various strategies were carried out in improving people's lives during the Covid-19 period, but real action was mainly to improve a better life during and after Covid -19 .
\end{abstract}

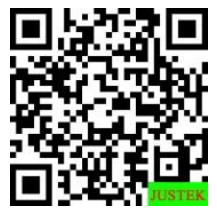

\begin{abstract}
Abstrak berbagai strategi pemerintah, Lembaga/swasta dan masyarakat dalam mempertahankan kehidupan dimasa Covid-19. Strategi penghidupan masyarakat Desa Seloto sebagai pusat perkembangan Amal Usaha Muhammadiyah (AUM) di Kabupaten Sumbawa Barat. Memiliki strategi penghidupan masyarakat beragam di sekitarnya. Penelitian ini bertujuan untuk mengkaji strategi penghidupan berkelanjutan masyarakat sekitar Amal Usaha Muhammadiyah pada masa covid 19 di Taliwang Sumbawa Barat. Metode yang digunakan dalam penelitian ini adalah deskriptif. Hasil dari penelitian ini menunjukan bahwa strategi pertama, strategi intensifikasi, pada masa Covid-19 tertinggi terdapat di Dusun Brang Pandan dan Brang Bulu rata-rata mencapai 18,15 dan paling rendah di miliki pada Dusun Brang Late mencapai 37,47. Srategi Kedua, strategi diversifikasi, pada masa Covid-19 tertinggi terdapat di Dusun Lenang Late rata-rata mencapai 18,15 dan paling rendah di miliki pada Dusun Brang Bulu mencapai 13,30. Dan Strategi ketiga, strategi migrasi pada masa Covid-19 sama-sama dari ketiga dusun tersebut rata-rata rendah mencapai 2 . Berbagai strategi dilakukan dalam meningkatkan kehidupan masyarakat masa Covid-19, namun aksi nyata terutama meningkatkan kehidupan yang lebih baik masa dan pasca Covid-19
\end{abstract}




\section{A. LATAR BELAKANG}

Desa merupakan bagian terkecil dari wilayah Indonesia dengan kondisi masih jauh dari kemandirian dalam pembangunan. Desa merupakan salah satu pusat dari masyarakat tertinggal/miskin. Kemiskinan sebagai suatu fenomena sosial ditengah masyarakat yang dialami oleh semua negara. Fenomena ini pada dasarnya telah menjadi perhatian, isu,dan gerakan global yang bersifat kemanusiaan (humanity).

Kabupaten Sumbawa Barat sebagai kabupaten yang memiliki program dalam penanggulangan kemiskinan diakui secara nasional dalam bidang gotong royong. Melalui Peraturan Daerah No. 3 Tahun 2016 Tentang Program Daerah Pemberdayaangotong Royong (PDPGR). Peraturan ini diperkuat dengan implementasi melalui Peraturan Bupati Sumbawa Barat Nomor 19 Tahun 2016 tentang Petunjuk Pelaksanaan PDPGR. Lahirnya pertauran ini sebagai satu-satunya program gotong royong yang masih berlaku di Indonesia.

Keberadaan program tersebut, masih tingginya tingkat kemiskinan yang dimiliki. Fenomena ini ternyata terjadi ditengah masyarakat kabupaten Sumbawa Barat. Berdasarkan garis kemiskinan dan persentase penduduk miskin di Kabupaten Sumbawa Barat (Tabel 1) menunjukan bahwa tingkat kemiskinan ditanah dengan motto "Pariri Lema Bariri" tersebut. Berdasarkan data penduduk miskinnya dari tahun 2012 s/d 2018 memiliki tinggi kemiskinan masih tinggi.

Tabel 1 Garis Kemiskinan dan Persentase Penduduk Miskin

\begin{tabular}{|c|c|c|}
\hline \multirow{2}{*}{ Uraian } & Jumlah & Persentase \\
\cline { 2 - 3 } & Penduduk Miskin & Penduduk Miskin \\
\hline (Tahun) & (Orang) & $(\%)$ \\
\hline 2012 & 21.724 & 17,61 \\
\hline 2013 & 21.710 & 17,10 \\
\hline 2014 & 22.710 & 16,87 \\
\hline 2015 & 22.500 & 16,97 \\
\hline 2016 & 22.470 & 16,50 \\
\hline 2017 & 22.330 & 15,96 \\
\hline 2018 & 20.360 & 14,17 \\
\hline
\end{tabular}

Sumber : BPS Kabupaten Sumbawa Barat, 2020

Berdasarkan data tersebut menunjukan bahwa jumlah penduduk miskin masih tinggi, padahal daerah memiliki sumberdanya alam yang dapat memberikan manfaat bagi masyarakat. Pernyataan ini diperkuat bahwa Kabupaten Sumbawa Barat merupakan salah satu kabupaten yang kaya akan sumber daya alam yang dikelola oleh PT. Newmont Nusa Tenggara. Namun, masyarakat sekitar areal tambang emas secara umum sampai saat ini masih miskin (Ibrahim, Baiquni, Ritohardoyo, \& Setiadi, 2016).

Permasalahan tersebut harus segera diselesaikan salah satunya dengan memaksimalkan potensi pertanian. Namun berbagai program Pemberdayaan masyarakat dilakukan dengan mengoptimalkan program desa berbasis potensi lokal masyarakat. Perubahan bagi masyarakat terlebih pada peningkatan pengetahuan dan perekonomian masyarakat. Pemberdayaan dan partisipasi dilakukan sepenuhnya bisa melalui program pemerintah, swasta/Lembaga dan masyarakat. Bahkan kenyataan banyak masyarakat melakukan aktivitas pemebrdayaan atas nama pribadi dan kelompok. Namun pelaksanaannya masih membutuhkan partisipasi unsur-unsur masyarakat lain yang akan mendukung program pemberdayaan tersebut. 
Muhammadiyah merupakan organisasi keagamaan dengan senantiasa berpegang pada amar ma'ruf nahi munkar terbukti telah berperan aktif dalam pemberdayaan masyarakat baik dalam bidang keagamaan, pendidikan, kesehatan, ekonomi maupun sosial kemasyarakatan lainnya. Kondisi komunitas kokoda miskin dan sangat memprihatinkan (Edyanto, 2019). Kehadiran Muhammadiyah sebagai alternatif dalam menyelesaikan kemiskinan ditingkat Cabang dan ranting pada seluruh Indonesia. Berbeda dengan pelaksanaan program pemberdayaan di tingkat Cabang dan ranting belum menunjukan hasil yang maksimal. Berdasarkan laporan Pimpinan Wilayah Muhammadiyah (PWM) Nusa Tenggara Barat (2018) dalam realisasi program kerja Tahun 2018 ternyata pada Majelis Pemberdayaan Masyarakat (MPM) mencapai 0 persen. Kondisi ini karena belum memiliki program dalam penanggulangan kemiskinan sampai tingkat Cabang dan ranting.

Karakteristik sosial ekonomi masyarakat sekitar Aamal Usaha Muhammadiyah (AUM) di Seloto Kabupaten Sumbawa Barat, dilihat dari aspek umur, mayoritas masih tergolong dalam masyarakat yang berumur produktif mencapai 39,19 persen, jumlah anggota keluarga tertinggi mencapai 71.01 persen pada kategori kurang dari 4 orang, Jumlah Anggota Keluarga 4-7 orang mencapai 23,19 Persen dan diatas 7 orang tererendah mencapai 5,80 persen. Pendidikan kepala keluarga tertinggi Sekolah Dasar (SD) mencapai 55,07 persen dan tidak sekolah, Sekolah Menengah Pertama, Sekolah Menengah Atas dan Sarjana rata-rata dibawah 50 persen. Pekerjaan utama sebagai petani tertinggi mencapai 68.12 persen, pekerjaan lain diluar petani (nelyan, wiraswasta, karyawan dan PNS) masih rendah dibawah 50 persen. Karakteristik social ekonomi masyarakat sekitar Amal Usaha Muhammadiyah sangat beragam. Informasi penelitian ini dapat sebagai dasar dalam pengambilan kebijakan dalam mengembangkan program berbasis social ekonomi masyarakat sekitar Amal Usaha Muhammadiyah khususnya ditingkat ranting(Ibrahim \& Mintasrihardi, 2020).

Berbagai strategi dalam mendukung ekonomi masyarakat sekitar Amal Usaha Muhammadiyah, namun belum berhasil. strategi pemberdayaan ekonomi amal usaha muhammadiyah adalah belum dapat dilaksanakan sesuai dengan rencana strategis amal usaha muhammadiyah. Pelaksanaan program masih belum maksimal, karena pengurus masih fokus dalam penyelesaian konflik ditingkat internal. Diperlukan adanya kesadaran dari semua pengurus wilayah sampai tingkat ranting di Kabupaten Sumbawa Barat untuk duduk bersama, sehingga perseolan bisa diselesaikan secara lebih bijak dan dapat mengembangan amal usaha lebih baik di masa datang (Alil, 2019).

Covid-19 telah menjadi wabah pandemi global. Virus tak kasat mata ini tidak hanya mengancam keselamatan jiwa manusia saja, tetapi juga telah memorakporandakan sektor ekonomi dan sosial secara luas. Untuk meminimalisir dampak Covid-19, semua kalangan dituntut untuk berperan aktif dan nyata dalam mengatasinya, termasuk Muhammadiyah. Dengan seluruh sumber daya yang dimiliki, Muhammadiyah telah berikhtiar secara maksimal untuk berkontribusi dalam penanganan Covid-19. Muhammadiyah telah membentuk semacam gugus tugas bernama Muhammadiyah Covid-19 Command Center (MCCC) yang menjadi garda terdepan dalam penanggulangan Covid-19 di tanah air. Selain itu juga, Muhammadiyah mendukung kebijakan-kebijakan pemerintah dalam menjalankan protokol kesehatan dalam rangka pencegahan penularan Covid-19, terutama terakit dengan pemberlakukan social/physical distancing (Falahuddin, 2020).

Berbagai Langkah strategis Muhammadiyah dalam menjaga keselamatan masyarakat terutama mempertahankan ekonomi sebagai bentuk peran aktif di tengah masyarakat. Peran aktif Muhammadiyah belum dapat di terapkan pada ting Cabang dan ranting mengingat memiliki karakteristik yang beda. Diperlukan strategi yang mampu 
memberikan kemanfaatan dalam mempertahankan kehidupan di masa Covid-19 terutama sekitar Amal Usaha Muhammadiyah. Berdasarkan identifikasi tersebut strategi yang dilakukan pada pengurus wilayah Muhammadiyah sebgai alternatif. Pada penelitian ini penting untuk mengkaji strategi penghidupan berkelanjutan masyarakat sekitar Amal Usaha Muhammadiyah pada masa covid 19 di Taliwang Sumbawa Barat

\section{B. METODE PENELITIAN}

Jenis penelitian yang digunakan dalam penelitian ini adalah penelitian kuantitatif dengan menggunakan metode survey yakni suatu metode penelitian yang bertujuan untuk mengumpulkan sejumlah besar data berupa variabel, unit atau individu dalam waktu yang bersamaan. Metode survey yang digunakan dalam penelitian ini kemudian dianalisis secara deskriptif.

Kajian pada tingkat mikro dalam penelitian ini menggunakan penelitian survei. Unit analisis penelitian adalah rumah tangga yang diwakili oleh Kepala Keluarga [KK] sebagai responden. Pelaksanaan penentuan sampel responden menggunakan tehnik proportional sampling.

Tabel 2. Jumlah Desa, Dusun Dan Sampel Penelitian

\begin{tabular}{|l|c|c|c|c|}
\hline Kabupaten & \multicolumn{3}{|c|}{ Sumbawa Barat } & Jumlah \\
\hline Kecamatan & \multicolumn{3}{|c|}{ Taliwang } & 1 \\
\hline Desa & \multicolumn{3}{|c|}{ Seloto } \\
\hline Dusun & Brang Bulu & $\begin{array}{c}\text { Brang } \\
\text { Pandang }\end{array}$ & Lenang Late & 3 \\
\hline Jumlah RT / Dusun & 410 & 450 & 390 & 1040 \\
\hline Jumlah Sampel RT & $\mathbf{4 1}$ & $\mathbf{4 5}$ & $\mathbf{3 9}$ & $\mathbf{1 0 4}$ \\
\hline
\end{tabular}

Sumber : Analsis Data Sekunder, 2020

Berdasarkan Tabel 3 di atas menunjukan bahwa populasi setiap sampel desa terpilih berdasarkan pada proportional sampling. Penentuan sampel responden rumah tangga menggunakan sampel sebesar 10 persen. Persebaran responden pada lokasi penelitian berdasarkan jumlah populasi rumah tangga dikalikan jumlah responden rumah tangga dibagikan jumlah populasi rumah tangga pada lokasi penelitian. Jumlah sampel responden pada masing-masing lokasi penelitian sebanyak 104 responden.

Teknik pengumpulan data dalam penelitian ini menggunakan observasi, dokumentasi dan quesioner. Analisis data yang digunakan adalah analisis statistic deskriptif dengan menghitung nilai rata-rata. Analisis deskriptif digunakan untuk menghasilkan gambaran dari data yang telah terkumpul berdasarkan jawaban responden melalui distribusi item dari masing-masing variabel.

\section{HASIL DAN PEMBAHASAN}

Strategi penghidupan merupakan kegiatan mengatur atau merencanakan dengan cermat dalam merespon perugahan dalam kehidupan secara cermat untuk memperoleh target atau sasaran yang diinginkan. Strategi penghidupan berkelanjutan masyarakat sekitar Amal Usaha Muhammadiyah pada masa covid-19 ini pada tiga dusun di Desa Seloto Kecamatan Taliwang Kanupaten Sumbawa Barat.

Strategi penghidupan setidaknya menjadi tiga golongan besaryaitu; rekayasa sumber penghidupan pertanian yaituintensifikasidan ekstensifikasi,pola keragaman penghidupan (diversifikasi) dan,rekayasa spasial (migrasi)(Wijayanti, Baiquni, \& Harini, 2016). Pemaduan pengelompokan tipologi strategi tersebut disesuaikan dengan kondisi keragaman dan karakteristik masyarakat sekitar amal usaha Muhammadiyah pada masa Covid-19. Strategi masyarakat pada masing-masing rumah tangga yang mencerminkan 
keterlibatan rumah tangga tersebut kedalam suatu aktifitas ekonomi. Startegi masyarakat secara rinci di jabarkan sebagai berikut.

\section{Strategi Intensifikasi}

Strategi yang tepat untuk meningkatkan ketahanan pangan melalui penggunaan Dana Desa di Desa Kuwu adalah untuk mendukung kebijakan pertumbuhan agresif dengan memaksimalkan kekuatan dan peluang seperti meningkatkan kapasitas produksi pangan dengan intensifikasi dan diversifikasi, pengembangan sumber daya manusia, dan meningkatkan infrastruktur jalan bisnis petani (Yuliana, 2018).

Dalam penelitian ini, strategi diversifikasi nilai gabungan pemnafaatan lahan pertanian yang ada, pemanfaatan pekarangan dan penambahan lahan garapan. Strategi intensifikasi masyarakat pada masa covid-19 guna mendukung penghidupan berkenjutan. Berbagai strategi intensifikasi dilakukan masyarakat perdesaan karena masyarakat desa memiliki tingkat kemudahan dalam pemanfaatan lahan sekitar perumahannya. Persebaran strategi intensifikasi secara rinci pada gambar 1 berikut.

Gambar 1. Startegi Intensifikasi

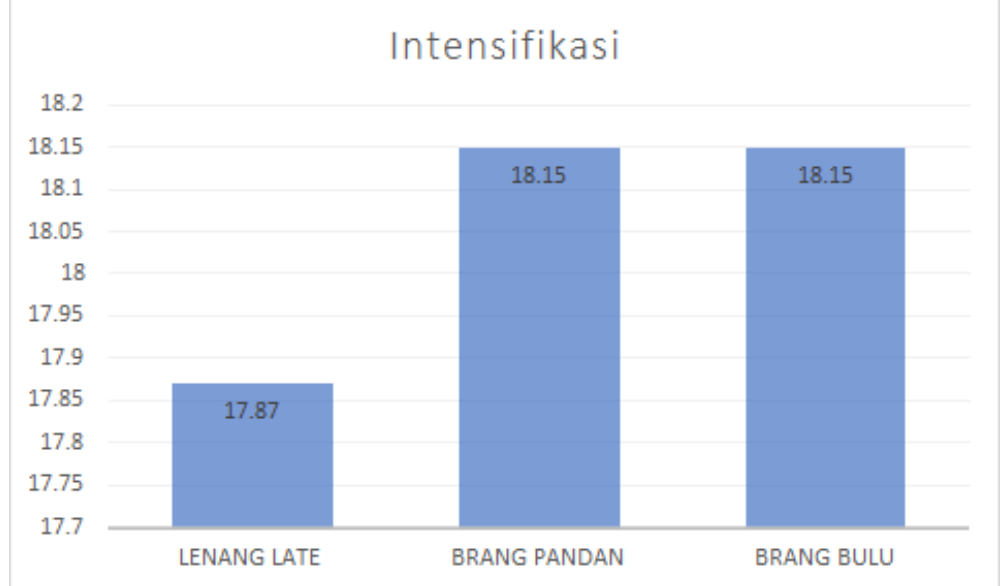

Mencermati Gambar 1 strategi intensifikasi dalam kehidupan masyarakat berkelanjutan pada masa Covid-19 tertinggi terdapat di Dusun Brang Pandan dan Brang Bulu rata-rata mencapai 18,15 dan paling rendah di miliki pada Dusun Brang Late mencapai 37,47. Tingkat strategi intensifikasi melalui pemnafaatan lahan pertanian yang ada, pemanfaatan pekarangan dan penambahan lahan garapan sebagai strategi bertahan hidup menuju penghidupan berkalanjutan pada masa Covid-19. Pemanfaatan lahan pekarangan sebagai alternatif dalam bertahan hidup di masa Covid-19 masyarakat sekitar Amal Usaha Muhammadiyah.

Pemanfaatan pekarangan dan garapan sekitar rumah dalam mencukupi kebutuhan masyarakat sekitar Amal Usaha Muhammadiyah. pola adaptasi ekologi Pangumbahan desa antara lain ditentukan oleh adanya konsesi perkebunan dan konservasi penyu yang membatasi kehadiran budaya masyarakat desa Pangumbahan. Keterbatasan sumber daya alam, manusia dan rumah tangga kekuatan keuangan untuk melakukan berbagai strategi untuk bertahan hidup. Strategi yang dilakukan warga desa pendapatan rumah tangga Pangumbahan bervariasi. Dalam satu rumah tangga dapat menerapkan dua atau lebih jenis strategi penghidupan(Tridakusumah, Elfina, \& Mardiyaningsih, 2015).

Kondisi ini diperkuat Bentuk-bentuk bertahan hidup (survival) dan keluar (exit) dari kemiskinan yang dilakukan oleh orang miskin dan rumah tangga miskin beragam sesuai dengan penyebab kemiskinan. Mengurangi rumah tangga miskin bukanlah dengan program dan kebijakan yang terpisah dari penyebab kemiskinan. Program yang terpisah 
tersebut akan membuat kemiskinan baru karena program tersebut tidak menyasar pengurangan kemiskinan. (Asyari, 2017)

\section{Strategi Diversifikasi}

Penduduk desa masih menggantungkan kehidupan mereka dari kegiatan pertanian. Lahan yang digunakan adalah prinsip bajak sendiri. Strategi nafkah warga yang tinggal di desa ini tidak hanya dari sektor pertanian, tapi juga sektor non pertanian. Terdapat berbagai cara penerapan struktur strategi penghidupan, mulai dari intensifikasi satu sektor, diversifikasi pendapatan atau pola nafkah ganda, rekayasa spasial atau migrasi. Namun, semua sektor pendapatan tetap menggunakan modal. Kelima modal yaitu modal sumberdaya alam, modal sosial, modal manusia, modal finansial, dan modal fisik digunakan sebagai cara untuk mendukung keberlanjutan strategi nafkah mereka. Bahkan semakin lama, warga cenderung lebih bergantung pada sektor non petanian. Namun basis nafkah mereka adalah sebagai petani. Hal ini dapat disimpulkan bahwa telah terjadi transformasi sosial dimana nilai pertanian terhadap masyarakat telah menurun (Fridayanti \& Dharmawan, 2015).

Dalam penelitian ini, strategi diversifikasi nilai gabungan dari penghasilan dari pertanian, penghasilan luar pertanian dan penghasilan, modal dan penambahan jam kerja dari kerja sampingan. strategi diversifikasi masyarakat sebagai alternatif dalam bertahan hidup pada masa covid-19. strategi diversifikasi pada lokasi penelitian memiliki tingkat strategi diversifikasi memiliki tingkat rata-rata. Persebaran strategi diversifikasi secara rinci pada gambar 2 berikut.

Gambar 2. Strategi Diversifikasi

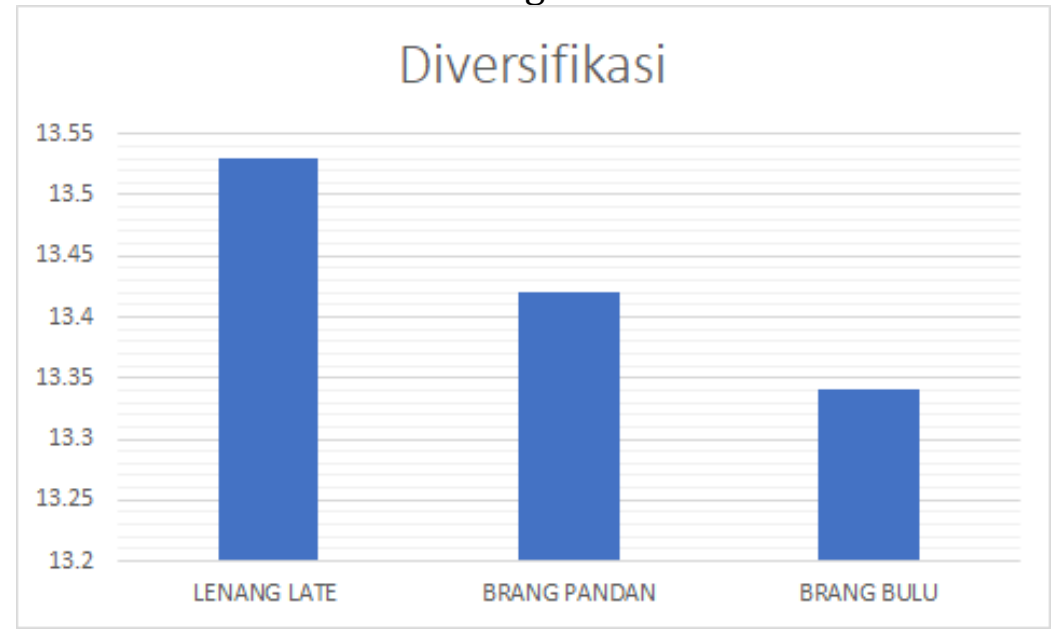

Mencermati Gambar 2 strategi diversifikasi dalam kehidupan masyarakat berkelanjutan pada masa Covid-19 tertinggi terdapat di Dusun Lenang Late rata-rata mencapai 18,15 dan paling rendah di miliki pada Dusun Brang Bulu mencapai 13,30. Tingkat strategi diversifikasi melalui pengolahan hasil pertanian dan luar pertanian sebagai strategi bertahan hidup menuju penghidupan berkalanjutan pada masa Covid-19. Pertanian sebagai salah satu penghasilan utama masyarakat Desa Seloto sehingga masyarakat sekitar Amal Usaha Muhammadiyah.

Pengolahan hasil pertanian dan luar pertanian sebagai strategi utama dalam mencukupi kehidupan masyarakat pada masa Covid-19. strategi pengembangan potensi wilayah agroindustri perkebunan unggulan berada pada kuadran I ataustrategi yang dibuat dengan menggunakan seluruh kekuatan untuk memanfaatkan peluang yaitu strategi agresif denganmelakukan peningkatan kemandirian petani melalui pembinaan dan penyuluhan, pengembangan kemitraan pada kegiatan agroindustri dalam upaya menambah nilai tambah produksi (Herdhiansyah, Sutiarso, Purwadi, \& ., 2012). 
Guna menguatkan pernyataan tersebut bahwa dalam rangka menangani dampak ekonomi COVID-19 dengan memaksimalkan kawasan agropolitan. Fomulasi dengan memaksimalkan pengembangan kawasan agropolitan dengan penguatan regulasi serta perluasan kawasan agropolitan ke wilayah/kota lain, dan memanfaatkan media online di dalam pelaksanaan termasuk sistem pemasaran produk dari kawasan agropolitan ini meskipun sedang dalam masa pandemic (Ulya, 2020).

\section{Strategi Migrasi}

Dari perspektif produksi atau hulu, para petani dan produsen makanan mulai merasakan perubahan terkait pasokan input dan juga harus menyesuaikan protokol berproduksi untuk menjamin kualitas dan keamanan pangan di tengah pandemi Covid19, khususnya di wilayah yang sudah terkontaminasi. Mobilisasi bahan pangan juga akan mengalami beberapa penyesuaian di mana terjadi pola perubahan jalur pasokan yang lebih banyak menuju pasar-pasar modern dan pasar yang berbasis online. Sementara itu dari sisi konsumsi, akibat diterapkannya social/physical distancing atau Pembatasan Sosial Berskala Besar (PSBB) di beberapa wilayah, pola transaksi juga mulai berubah yang ditunjukkan semakin meningkatnya transaksi yang menggunakan platform digital atau online. Kondisi inilah yang pada akhirnya membutuhkan penyesuaian strategi kebijakan terkait pangan di semua lini (produksi hingga konsumsi dan hulu hingga hilir) agar ketahanan pangan di Indonesia tetap terjamin.(Hirawan \& Verselita, 2020).

Keberadaan bencana Covid-19 membutuhkan strategi alternatif untuk bertahan hidup. Pertanian adalah sektor penopang ketahanan pangan (food security) yang akan krusial di kala krisis ekonomi. Ini bukan hanya sebatas bertahan hidup tapi juga masalah asupan gizi masyarakat. Persebaran strategi diversifikasi secara rinci pada gambar 3 berikut.

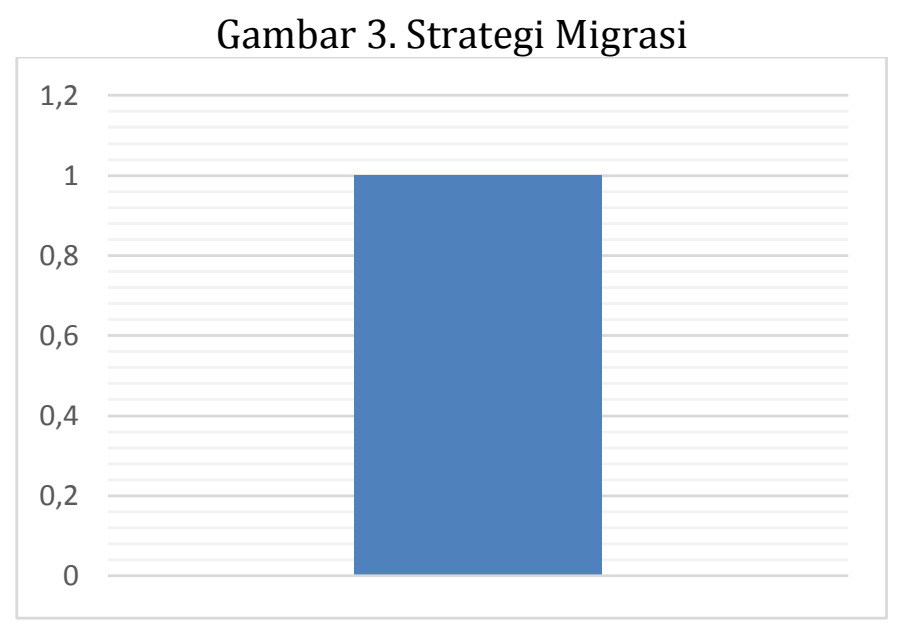

Mencermati Gambar 3 strategi migrasi dalam kehidupan masyarakat berkelanjutan pada masa Covid-19 sama-sama dari ketiga dusun tersebut rata-rata rendah mencapai 2. Artinya bahwa strategi migrasi meruoakan bukan solusi dalam bertahan hidup masayarakat sekitar Amal Usaha Muhammadiyah di masa covid-19 di Desa Seloto Kabuapten Sumbawa Barat. Mengingat nilai kkeluarga dalam masyarakaat perdesaan masih sangat tinggi.

Tetangga merupakan seseorang dalam satu lingkup satu daerah atau tempat tinggal, memiliki jiwa sosial yang tinggi untuk saling menolong saudaranya yang mengalami kesusahan. Suasana ini masih terlihat jelas didaerah penelitian, disaat rekan-rekan mereka mengalami masa krisis ataupun masa-masa sulit, 
Kearifan lokal yang berkembang di masyarakat, pada dasarnya merupakan strategi adaptasi yang memang muncul dari dalam masyarakat itu sendiri dalam membenahi masalah-masalah sosial yang berkenaan dengan kehidupan masyarakat itu sendiri. Kearifan lokal merupakan hasil interaksi antara masyarakat dengan lingkungannya, sehingga dengan kearifan lokal, sangat diperlukan untuk membantu masyarakat itu secara mandiri. Kearifan lokal menjadi inti dari usaha mengentaskan kemiskinan yang ada dan tumbuh di masyarakat sebagai sasaran dari proses penerapan program pengentasan kemiskinan. Pengembangan kesejahteraan sosial atau juga pembangunan komuniti (community development) termasuk didalamnya program pengentasan kemiskinan dapat dilaksanakan dengan penerapan yang sesuai melalui kacamata komuniti setempat sebagai obyek sasaran (., 2009).

Kondisi ini menunjukkan, bahwa diantara mereka mempunyai solidaritas yang kuat dan saling percaya. Keberadaan tetangga maupun teman merupakan tumpuan untuk memperoleh pertolongan dan sebagai tempat pertama yang akan dituju apabila mereka mengalami masalah

\section{SIMPULAN DAN SARAN}

Dari hasil penelitian dan pembahasan diatas dapat disimpulkan bahwa strategi penghidupan berkelanjutan masyarakat sekitar Amal Usaha Muhammadiyah pada masa covid 19 di Taliwang Sumbawa Barat adalah (1) strategi intensifikasi, pada masa Covid-19 tertinggi terdapat di Dusun Brang Pandan dan Brang Bulu rata-rata mencapai 18,15 dan paling rendah di miliki pada Dusun Brang Late mencapai 37,47; (2) strategi diversifikasi dalam kehidupan masyarakat berkelanjutan pada masa Covid-19 tertinggi terdapat di Dusun Lenang Late rata-rata mencapai 18,15 dan paling rendah di miliki pada Dusun Brang Bulu mencapai 13,30 dan (3) strategi migrasi dalam kehidupan masyarakat berkelanjutan pada masa Covid-19 sama-sama dari ketiga dusun tersebut rata-rata rendah mencapai 2. Berbagai strategi dilakukan dalam meningkatkan kehidupan masyarakat masa Covid-19, namun aksi nyata terutama meningkatkan kehidupan yang lebih baik masa dan pasca Covid-19.

\section{UCAPAN TERIMA KASIH}

Penelitian ini dibiyai dari Hibah PP Muhammadiyah. Terima kasih pada semua pihak terutama Pengurus Wilayah NTB, Pengurus Cabang dan Ranting di Sumbawa Barata serta pihak-pihak yang telah mendukung penelitian ini.

\section{REFERENSI}

. S. (2009). Pemberdayaan Masyarakat Miskin Berbasis Kearifan Lokal. Sodality: Jurnal Sosiologi Pedesaan. Https://Doi.Org/10.22500/Sodality.V3i1.5873

Alil, I. (2019). Strategi Pemberdayaan Ekonomi Melalui Program Amal Usaha Muhammadiyah Pada Perdesaan Di Sumbawa Baratstrategi Pemberdayaan Ekonomi Melalui Program Amal Usaha Muhammadiyah Pada Perdesaan Di Sumbawa Barat. Jpek (Jurnal Pendidikan Ekonomi Dan Kewirausahaan). Https://Doi.Org/10.29408/Jpek.V3i2.1712

Asyari, A. (2017). Model Strategi Bertahan Hidup Rumah Tangga Miskin (Sebuah Literature Review). Islam Realitas: Journal of Islamic \& Social Studies. Https://Doi.Org/10.30983/Islam_Realitas.V2i2.186

Edyanto, K. (2019). Peran Muhammadiyah Dalam Pemberdayaan Masyarakat Kokoda Di 
Kota Sorong. Jurnal Noken: Ilmu-Ilmu Sosial. Https://Doi.Org/10.33506/Jn.V4i1.360

Falahuddin, F. (2020). Respons Muhammadiyah Menghadapi Covid-19. Maarif. Https://Doi.Org/10.47651/Mrf.V15i1.81

Fridayanti, N., \& Dharmawan, A. H. (2015). Analisis Struktur Dan Strategi Nafkah Rumahtangga Petani Sekitar Kawasan Hutan Konservasi Di Desa Cipeuteuy, Kabupaten Sukabumi. Sodality: Jurnal Sosiologi Pedesaan. Https://Doi.Org/10.22500/Sodality.V1i1.9388

Herdhiansyah, D., Sutiarso, L., Purwadi, D., \&. T. (2012). Strategi Pengembangan Potensi Wilayah Agroindustri Perkebunan Unggulan. Jurnal Teknik Industri. Https://Doi.Org/10.22219/Jtiumm.Vol13.No2.201-209

Hirawan, F. B., \& Verselita, A. A. (2020). Kebijakan Pangan Di Masa Pandemi Covid-19. Csis Commentaries.

Ibrahim, I., Baiquni, M., Ritohardoyo, S., \& Setiadi, S. (2016). Karakteristik Kemiskinan Masyarakat Perdesaan Pada Kawasan Pertambangan Emas Di Kabupaten Sumbawa Barat. Mimbar, Jurnal Sosial Dan Pembangunan, 32(1), 163. Https://Doi.Org/10.29313/Mimbar.V32i1.1583

Ibrahim, I., \& Mintasrihardi, M. (2020). Karakteristik Sosial Ekonomi Masyarakat Sekitar Amal Usaha Muhammadiyah Di Sumbawa Barat. Jurnal Geografi. Https://Doi.Org/10.24114/Jg.V12i02.17734

Tridakusumah, A. C., Elfina, M., \& Mardiyaningsih, D. I. (2015). Pola Adaptasi Ekologi Dan Strategi Nafkah Rumahtangga Di Desa Pangumbahan. Sodality: Jurnal Sosiologi Pedesaan. Https://Doi.Org/10.22500/Sodality.V3i3.10638

Ulya, H. N. (2020). Alternatif Strategi Penanganan Dampak Ekonomi Covid-19 Pemerintah Daerah Jawa Timur Pada Kawasan Agropolitan. El-Barka: Journal Of Islamic Economics And Business. Https://Doi.Org/10.21154/Elbarka.V3i1.2018

Wijayanti, R., Baiquni, M., \& Harini, R. (2016). Strategi Penghidupan Berkelanjutan Masyarakat Berbasis Aset Di Sub Das Pusur, Das Bengawan Solo. Jurnal Wilayah Dan Lingkungan. Https://Doi.Org/10.14710/Jwl.4.2.133-152

Yuliana, I. (2018). Village Funds Utilization Strategy To Improve Food Security. Efficient: Indonesian Journal of Development Economics. Https://Doi.Org/10.15294/Efficient.V1i2.30155 